\title{
THE PROTOTYPE OF FINANCIAL SYSTEM ON LOCAL TAX PAYERS AND TAX OFFICERS
}

\author{
Hendi Subandi and Ayu Fury Puspita \\ University of Brawijaya
}

\begin{abstract}
This study aims to determine the problems that occur in the practice of parking tax withholding and create a system in the form of SOP to reduce the number of local tax payers and tax officers that commit tax evasion in Malang, Indonesia. The object of this research is taxpayers in Malang. This study used qualitative descriptive method with data collection technique by interview, observation, and documentation.The results of this study indicate that the practice of parking tax withholding is still not in accordance with the SOP and tax regulations in Malang, Indonesia. Parking Tax Withholding in Malang, Indonesia also has problems causing leakage and loss of potential in Parking Tax such as lack of awareness of Parking Tax Payers, Self Assessment System implementation, unperforated ticket, lack of field supervision and free parking policy. This study also proposed improvements to SOP. SOP improvement proposal is expected to reduce taxpayers to commit tax evasion in Malang Town.
\end{abstract}

Keywords: $\quad$ Tax Evasion, Standard Operating Procedure, Tax Payers, Tax Officer

\section{INTRODUCTION}

Good governance is a kind of governance which is good, clean, transparent, accountable, and free from corruption, collusion, and nepotism in the public, government, taxation, or private. Good governance can be achieved if the people in the nation have good behavior and do not break the rules. Whereas, good governance cannot be achieved if the people in the nation do not have good behavior, including deviant behavior in taxation circle. One of that deviant behavior is tax evasion.

Some strategies to do are parts of tax planning that intend to get profit before the optimal tax by minimalizing the amount of payable tax. Neuroeconomics perspective becomes taxpayer knowledge to act and behave without releasing economic thought and psychological condition in determining tax planning decision that will be selected by taxpayer. Therefore, the role of the rationality generated from neuroeconomics perspective may encourage them to avoid the tax or to do tax fraud in order to minimalize the amount of tax that should be paid (Puspita, 2017).

The contribution of neuroeconomics for identifying economic behavior is by identifying the economic concept which is connected into psychological functions. 
Most of neuroeconomics techniques involve brain activities so that it can easily grow perception that neuroeconomics only develop the map of the brain's parts and the functions. But in fact, neuroeconomics gives instructions from different point of view so that it changes radically the understanding about how economic executive work especially to make decision. The decision obtained do not always follow the normative axiom that every process of making decision should be based on logic (Carameter 2006). This is also caused by human behavior which is also affected by affective potential (emotion including passion).

Neuroeconomics gives conclusive evidence that the product of economic behavior include more than two systems, such as cognitive (rational) and effective (irrational/emotional). Furthermore, neuroeconomics also shows economic design which reflects inappropriate behavior patterns which is built inside strict and normative constructions so that it can disown the flexibility and dinamics which is known as its behavioral characteristics. Neuroeconomics has not been able to give a set of perfect answers for all questions caused by complexity and intricacy of behavior (Puspita, 2017).

Related to the tax planning, the fraud which is done by taxpayer or tax evasion, from psychological point of view, if the taxpayer get used to do tax evasion, it is the same as getting used to always violate constitution and applicable tax laws (Puspita, 2017). And if his actions violating the constitution is not known by the fiscal, then the taxpayer will be happy because they will not get punishment and cause any desire to repeat that behavior in the period, and even it would be expanded not only violating the constitution, but also the other tax regulations.

Based on these, it is necessary to have standard operating procedure (SOP) in the financial system, such as accounting and tax systems. Romney and Steinbert (2015) said that SOP is a reference to do any assignment appropriate with functions and job assesment instrument of the government agencies based on technical, administrative, and procedural indicators according to the job management, job procedures and system into the work unit concerned. If it is associated with the world of taxation, especially tax evasion cases, system like SOP will be able to control and minimalize tax evasion and it will be able to manage deviant behavior, both of the fiscal and the taxpayer. The purpose of controlling is to make good governance which is free from corruption. Good governance is usually associated with internal control mechanism which aims to minimalize deviation or manipulation in organization, whether it is done by the employees or others, whether it is deliberate or not.

Various kinds of reality about not achieving target of tax revenue, including taxpayers who do not report all of their income, as well as the emergence of cases of cooperational tax evasion between revenue officer and taxpayer (Suminarsasi and Supriyadi, 2011). Malang is one of the city in East Java which has given an autonomy from the government to manage its own teritory, whether business, accounting, or tax. Malang is also densely populated area for tax revenues. Malang is also a potential area for tax evasion for the taxpayers. It is because there are still deviant behavior which is done by the taxpayers or fiscal. The taxpayers are believed to do more tax irregularities that culminate in the tax evasion to make the amount of tax that should be paid decrease. 
Based on Puspita (2017) research, tax evasion which has been done by the taxpayer is caused by deviant behavior of the taxpayer. When the tax evasion behavior which is done by them is not known by the fiscal, the taxpayer will be comfortable to do any tax evasion. Therefore, tax planning behavior by the taxpayer is not only influenced by the taxpayer internal system itself, but also influenced by the tax administration system which has been determined by the fiscal. It is proven by study that has been done by Ratsminassiwi and Subandi (2017) with Fajriana and Subandi (2017) which show that the lower the taxation system, the higher the tax evasion behavior. Hence, through this research, researcher want to know the taxpayer planning behavior and the fiscal and also to arrange SOP as a strategy to minimalize tax evasion done by the taxpayer and fiscal.

Based on the descriptions, it is necessary to have a controlling system in the form of SOP to control tax evasion for the taxpayer and fiscal. It is addressed to the taxpayer and fiscal. It is aimed for Malang City to have a good governance which is free from curruption. The purpose of this research is to make a system in the form of SOP in order to reduce the number of taxpayer and fiscal doing tax evasion. The provisions of this study are for corporate taxpayers, research can be used as a guide for payment and tax reporting; for the fiscal can be used as a tax collection guideline; for the government can be used as a tool to achieve good governance that is free from $K K N$ so that no parties are harmed from tax evasion done by the taxpayer and fiscal.

\section{Review Of Related Literature Good Corporate Governance}

Good Corporate Governance is structure which is arranged by stakeholders, shareholders, commisioners, and managers about the puropose and facilities to reach the purpose itself, and performance monitoring. According to National Committee of Governance Policy (2006), Good Corporate Governance (GCG) is necessary to encourage the existance of efficient, transparent, and consistent market to the legislation. In practice, GCG needs to be supported by three interconnected pillars, that are country and its administratives as a regulator, the world of business as the market players, and the society as the users of the products and services in the world of business. By the implementation of GCG, it is expected that there will be continuity between firms and stakeholders. Because of that, firms should ensure that the principles of Good Corporate Governance is applied in every aspect of business and in all companies. The principles of GCG have been arranged in the Indonesia General Guideline of GCG in 2006 by National Committee of Governance Policy, that are: (1) Transparency; (2) Accountability; (3) Responsibilty; (4) Independency; (5) Fairness and Equality.

According to Daniri (2005), firm which is consistent and commited in application of Good Corporate Governance mechanisms will exactly take benefits, such as (1) Being able to raise up support from stakeholders for the firm existence and several strategies and policies defined by the firm; (2) Being able to increase the share value of the firm in the long-period; (3) Being able to decrease agency cost; (4) Being able to decrease cost of capital. 


\section{Taxation}

Based on Regulation Number 16 year 2009 about fourth change on Regulation Number 6 year 1983 about General Provisions and Taxation Procedures, article 9 subsection 1, tax is compulsary contribution for the country that is owed by person or institution which is coercive according to regulation, without getting no honorarium directly and it is used for the country necessities for the greatest prosperity of the people. Other than by regulations, the definitions of tax is also explained by some experts. According to Mardiasmo (2009), tax is a mandatory fee in the form of money or goods levied by authorities on the basis of legal norms, to cover the cost of producing goods and collective services in achieving public welfare. Such two functions as proposed by Mardiasmo (2009), that are (1) Function of acceptance (Budgetary) is taxes serve as a source of funds for the government to finance state expenditures; (2) Function of regulation (Regulerend) is taxes serve as a measuring tool for implementing government policies outside the financial field, which is the social and economic fields. Thus, based on some opinions above, it can be concluded that the tax is a contribution paid to the state in the form of money according to the general provisions and taxation procedures. Furthermore, the tax is used to finance state expenditures that concern the interests of the wider society for the realization of welfare for the whole society.

\section{Tax Evasion}

Tax evasion is done by the taxpayer to minimize the payment of tax payable in a way that is illegal, unlawful, and not appropriate with the applicable tax laws. Mardiasmo (2009) defines tax evasion is an attempt made by the taxpayer to minimize his tax burden illegally, which is violating the tax laws. The taxpayers ignore the provisions of taxation, falsify documents or fill data incompletely and incorrectly. Mardiasmo (2009) said that several reasons that become taxpayer consideration to make tax avoidance are as follows: (a) The existence of opportunities because there are loopholes in the law or the provisions of taxation that has not set clearly on certain provisions; (b)Possible deeds whic are known are relatively small; (c) The benefits obtained are relatively large compared to the risks; (d) Taxation sanctions which are not too heavy; (e)Tax provisions do not apply equally to all taxpayers; (f) The implementation of law enforcement which varies.

Siahaan (2010) said that tax evasion is an effort taken by taxpayers to avoid tax obligations and included illegal acts for violating the tax laws. This action brings various consequences to various fields, covering the fields of finance, economics, and psychology. According to Siahaan (2010), tax evasion affects the macro economy. The following are the consequences of tax evasion in various areas of community life, such as (a) Finance; (b) Economics; (c) Psychics. 


\section{Information System}

According to Tuban (2005), the information system is a process that performs the functions of collecting, processing, storing, analyzing, and disseminating information for a particular purpose. Furthermore, O'Brien (2005) explains that the information system is an organized combination of human resources, hardware, software, communication networks, and data resources that serves to collect, change, and disseminate information within an organization. Stair and Reynolds (2010) states that the information system is a set of interconnected components that perform functions in collecting, manipulating, storing, and disseminating data and information and providing mutual mechanism in order to achieve a goal. The classification of benefits derived from information systems as presented by Hartono (2005), that are (1) to reduce the costs; (2) to reduce the errors; (3) to increase the speed of activities; (4) to improve the management of planning and controlling.

\section{Standard Operating Procedure (SOP)}

Every company or organization needs a guide to perform the tasks and functions of each element or unit of the company so that the standard operating procedure (SOP) becomes an important aspect for the company or organization. Lakshmi et al (2008) defines Standard Operating Procedure (SOP) is a document relating to procedures performed chronologically in running a job to obtain the most effective work of the workers with minimal cost. SOPs usually consist of benefits, when created or revised, method of writing procedures, and completed by the flowchart at the end. According to Hartatik (2014), standard operating procedure (SOP) is a set of written instructions used to perform routine or repetitive work within an organization. Sailendra (2015) defines the standard operation procedure as the guideline used to ensure the operational activities of the organization or company run smoothly.

Standard Operating Procedure (SOP) is the embodiment of internal control of a company or organization. The internal controls, standards and criteria that companies use to assess their control systems have been developed by the Committee of Sponsoring Organizations of the Treadway Commission (COSO). The control elements according to COSO (2013), as follows: (1) Controlling environment; (2) Risk assessment; (3) Controlling Activities; (4) Information and communication; (5) Supervisioning activities

\section{Principles of Standard Operating Procedure (SOP)}

The principles of Standard Operating Procedure proposed by Moekijat (2008) are (1) Simple, (2) Specialization, (3) Prevention of writing, movement, or unnecessary activities, (4) Seeking to get the best work flow and prevent obstacles, (5) Preventing job duplication (especially forms), (6) There are minimum exceptions to the rules, (7) Preventing unnecessary checks, (8) SOP provides continuous supervision of the work undertaken (9) Using the best office machine, (10) Using the best job sequence, (11) Each completed work should advance the work and pay attention to the purpose, (12) The administration job should be kept to a minimum, and (13) Use the best exclusion principle. Based on the above explanation, the SOP should be simple, use the best 
possible specialization, prevent duplication of work, and make the most of the time, equipment, work order, and ease in monitoring.

\section{Objectives and Benefits Standard Operating Procedures (SOP)}

Here are the purposes of SOP for companies according to Sailendra (2015). Purposes are:

a. Maintaining consistency of work of every officer, officer, team and all work units.

b. Clarifying the work flow, authority, and responsibilities of each work unit.

c. Facilitating the process of assigning tasks, responsibilities to the employees who run them, facilitating the process of controlling every work process, facilitating the process of understanding staff systematically and general, facilitating and knowing the occurrence of failure, inefficiency of work process, and the possibility of abuse of authority of employee.

d. Avoiding the errors of working process and avoiding mistakes, doubts, duplications and inefficiencies.

e. Protecting organizations or work units from various forms of administrative errors.

f. Providing information about documents required in a work process, and

g. Saving time in training programs, because Standard Operating Procedures (SPO) are

systematically arranged.

\section{RESEARCH METHODS}

\section{Research Objects}

The objects of research are the taxpayer agencies and the regional fiscal, because there are problems of reporting and tax management practices that are not appropriate with the income and profits generated by taxpayer institutions and corruption practices which are still being done. One of the problems is occurred in taxpayer agencies and fiscal in Malang, East Java, Indonesia.

\section{Research Methods}

This research is an action research. In the preparation of this report, researchers used the Waterfall Model in the System Development Life Cycle (SDLC) concept. SDLC model is in figure 4.1 below:

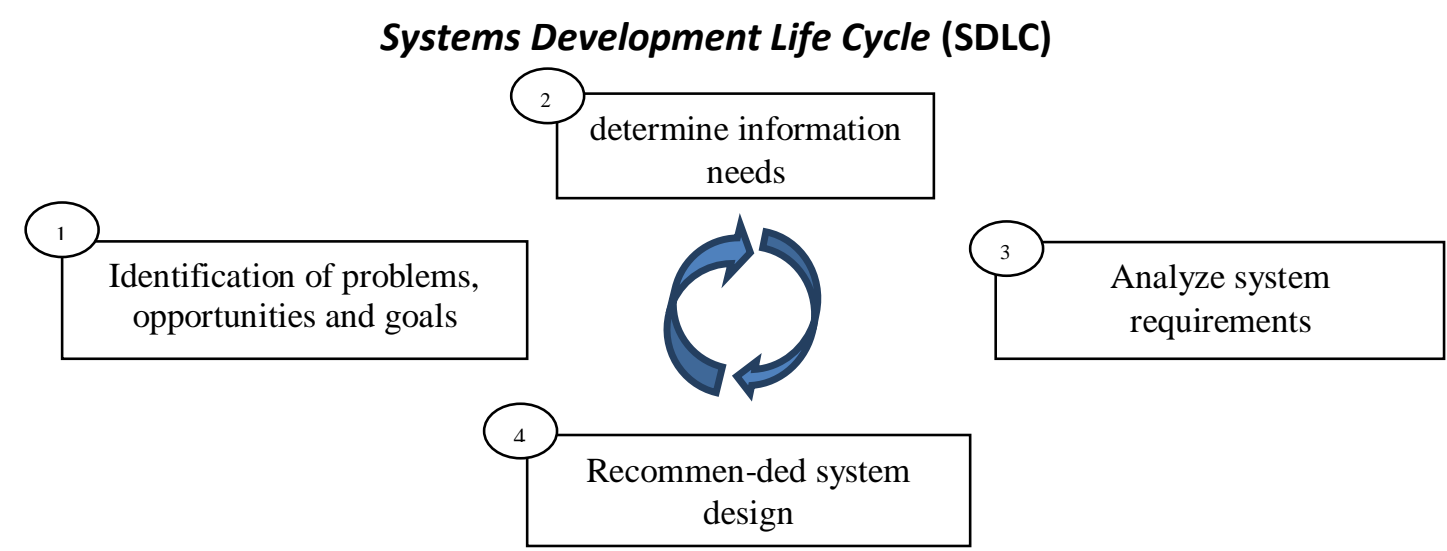


Source : Kendall, K.E. \& Kendall, J. E. (2003).

The waterfall model in this study only includes four stages as a form of evolution of the waterfall model because this research focuses only from design, implementation, to theevaluation as well as development of financial systems of the taxpayer agency and regional fiscal. The stages in this model are as follows:

1. Problems Identification, Opportunities, and Goals

Researchers look at the problem of deviant behavior, which is tax evasion on taxpayers agencies and fiscal, then plan the goals and financial system, namely accounting system and tax system for controlling corruption and achieving of the better good governance.

2. Determining The Necessity of Information

Collecting information about the complete financial system from the primary data source which is from interviews on taxpayer agencies and regional fiscals. Information is also obtained from secondary data which is from several preliminary study of performance based budget realization system. Furthermore, the information is analyzed and defined according to the needs that must be met by the system which is going to be built. This phase must be done completely to produce a complete system design.

3. Analysis of System Requirement

Researchers analyze the needs of financial systems such as policies and alternative conditions of each taxpayer agency and regional fiscal. Recommendations to the plan should be made to resolve governance issues in the taxpayers agencies and regional fiscal.

4. Recommended System Design

The design is done after the above three steps have been done by the researcher. The design of financial manual system is appropriate with the characteristics and policies of each taxpayers agencies and fiscal.

\section{Research Data Sources}

Sources of data used in this study are as follows (1) Primary Data Sources. This research data obtained through observation and interview. Observation is done through observation. While the interview will be conducted on: (a) Taxpayer Agency (taxpayer, tax cutter, fiscal, owner); (b) Regional Fiscal (fiscal, administrative). (2) Secondary Data Sources. Secondary data sources are complementary data sources that serve to complement the data required by the primary data. The secondary data sources are needed, namely regulations, books, empirical research, and documents related to accounting and taxation systems.

\section{Data Collecting Methods}

The data collecting procedure in action research is through three stages:

1. Orientation Stage. It is an early stage of the research done to obtain a clear and complete picture of the problem to be studied. Activities undertaken are 
conducting preliminary studies of various references such as empirical research conducted by Puspita (2017), Ratsminassiwi and Subandi (2017), and Fajriana and Subandi (2017).

2. Exploration Stage. This stage is the first stage of research activities that aims to dig information and collecting process through the research focus and objectives. This research is conducted after obtaining permission from the taxpayer agency and regional fiscal. Exploration activities include (a) Receiving an explanation from the taxpayer agency and the regional fiscal relating to the planning, implementation, assessment, and evaluation of the financial system; (b) Conducting verbal interviews on research objects to obtain about financial system activity planning, financial system implementation, and financial system evaluation; (c) Making observations on the activities associated with the financial system; (d) Making a rough note of the data collected from the research objects; (d) Selecting, compiling, and classifying data according to the research.

3. Member Check Stage. This stage is used to check the truth of the interview result information, observations, and documentation that have been collected so that researchers have a fairly good level of trust. Checking information and data can be done by the following techniques: (1) Arranging the interview results based on the items, arranging the observation results and then confirm the interview results and observations on the informant so that there is no misinterpretation in describing the data; (2) Proposing observed interview results from observations of the informant; (3) The enhancement of validity is done by triangulation of the information truth from informant and observations.

\section{Research Instruments}

The instruments of this research are done by observation and interview method. The interview is done structured and unstructured. (a) Structured interviews.Structured interviews are conducted by compiling questions in a coherent manner from simple questions to core questions related to tax planning by the taxpayers agencies and fiscal; (b) Unstructured interview. Unstructured interviews are conducted by randomly asking questions of taxpayers of agencies and fiscal. This is done for digging deeper information about organizational structure, job description, business process, financial system used, accounting and financial policies, and management policies.

\section{DISCUSSION}

\section{Taxpayer Agency in Malang}

Malang is a densely populated area with great potential for tax revenue. Many companies are established in Malang, both in the form of PT and CV. Ratsminassiwi \& Subandi (2017) define that in the taxpayer agency, the parts that understand related to finance, accounting, and taxation system in Malang City are Financial Manager and Accounting and Financial Clerk. The tax system, including tax collecting system is an important component in supporting the success of tax collection in Indonesia. In 
general, in collecting taxes known some collection system (Official, 2013), namely: (a) official assessment system; (b) self assessment system, and (3) with holding system.

But since the tax reform in 1983 one of the changes that occurred in the tax system in Indonesia is the tax collecting system called official assessment system that turned into a self assessment system. In this system the taxpayer is given full trust by the government to be able to register as a Tax Payer, calculate, deposit and report the amount of payable tax in accordance with the period specified in the applicable legislation. To realize the self assessment system is required compliance of the Taxpayer itself and most important is the understanding of the applicable Law (Wahyuni, 2011). But not all the potential taxes are dug maximally due to the number of taxpayers who do not have awareness of the importance of fulfillment of tax obligations as a good citizen. It is necessary for the society to have a high level of voluntary tax awareness (voluntary tax compliance) to be able to optimize the self assessment system (Suminarsasi, 2011).

Basically, the purpose of applying the self assessment system is very good, that is to raise awareness of the importance of paying taxes where the tax itself is used by the government to finance public expenditures. However, in practice, the tax is considered as a burden (tax burden) by the Taxpayer, so there are many cases where the Taxpayer is dishonest in reporting and depositing the tax payable. Tax perception as the burden is what makes Taxpayers to conduct tax evasion and tax avoidance, although in practice tax evasion is allowed for looking for loopholes of the Tax Law. This is a very fundamental constraint of applying the self assessment system where this system gives the Taxpayer the full confidence to calculate the tax payable.

\section{Malang Overview Parking Condition}

Parking revenue in Malang City is one of the Original Regional Income (PAD) for Malang City. The parking income in Malang City is divided into Retribution and Parking Tax. The parking charges are managed directly by the Transportation Department while the Parking Tax is managed by the Regional Revenue Service. Although it is managed by different Office, eventually it will enter at the same place which is Malang Region Treasury.

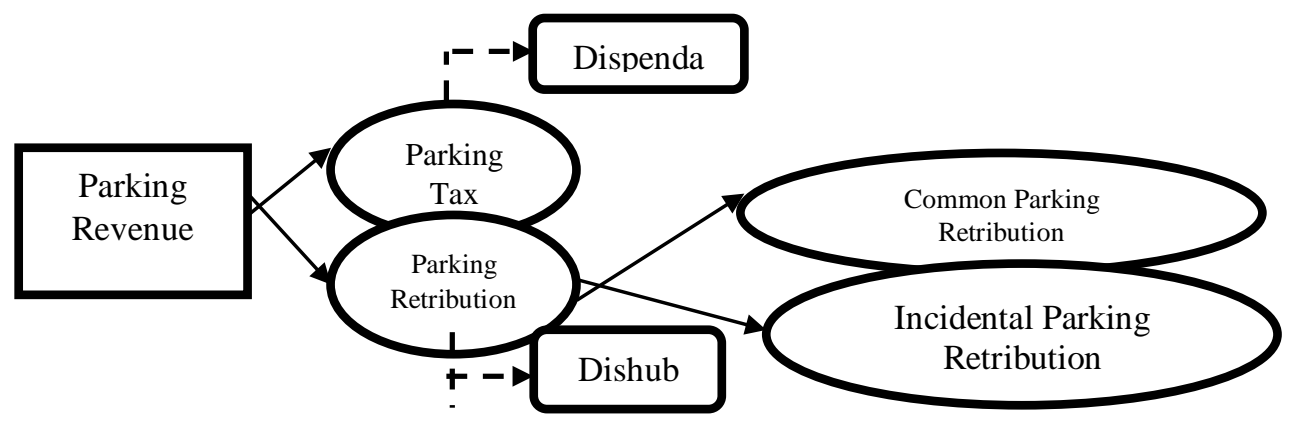

Figure 4.1 Chart Source of Parking Revenue at Malang

Based on Mayor Regulation Number 15 Year 2011 article 1 it is explained that the parking tax is a tax on the off-street parking spaces provision, whether provided in 
connection with the principal business as well as that provided as a business, including the provision of motorized daycare. The tax bases are further explained in article 26 which is the amount of payment or which should be paid to the parking lot. The tax payable is calculated by multiplying the parking tax rate (article 27 ) by $20 \%$ on the taxation basis.

Parking retribution according to Malang District Regulation No. 3 of 2015 article 1 is a regional charges as payment for certain services or licenses (in this case parking) specifically provided and/or provided by the Regional Government for the individual benefit or instances. The parking charges come from public parking lots and incidental parking spaces. Public Parking spaces are roadside or shopping malls that not contradict with traffic signs and other similar venues that are allowed for public parking spaces and are used to place motor vehicles and/or non-temporary vehicles. Related to incidental parking spaces are parking spaces held temporarily or not permanently due to an interest or activity. An example of this incidental parking lot is a parking lot located at Pasar Tugu Market which is held every Sunday.

\section{RESEARCH FINDINGS}

\section{Lack of Parking Taxpayer Awareness}

Taxpayer awareness in paying the parking tax is an important thing in order to increase the Original Regional Income (PAD). Unfortunately, the tax perception as a burden (tax burden) is embedded in the Taxpayer with the addition of corruption cases that make Taxpayers are so "reluctant" to pay the taxes. The practice of collecting parking tax in Malang City found that Taxpayers' awareness is low enough to pay parking tax. The impact of this issue in paying the parking tax affects the low tax compliance of both administrative tax compliance and technical tax compliance. The case encountered in the city of Malang is a Taxpayer (in this case the taxpayer of the Agency) does not deposit parking tax in accordance with the rules or even not at all deposit to Dispenda Malang because they already claimed that they have deposited to the local village cash. This is known from the interview Mr. X.

"The average of rented land is a Bangkok property so they thought that they already deposit to the village, they felt they already do his obligation to pay their taxes. ... he felt that he is just a villager, an indigenous person, so he thought there is an established tax object there. At the end, he paid the taxes not in accordance with the turnover. So he is just pay the taxes for just limited liability only. (July 6, 2017: 09:30 WIB)."

\section{Self Assessment System Policy}

Self Assessment System is a system that entrusts Taxpayers to calculate, calculate, deposit and report their own taxes. The problem that met in this system is the Taxpayer itself. Taxpayers have full responsible to calculate the taxation that in practice Taxpayers itself did cheat to be able to minimize deposit taxation. In the case of parking tax, it found Taxpayers (in this case the Agency) commits fraud in reporting income received from providing parking spaces. Whereas this revenue received by the organizer is the taxation basis which is then multiplied by the tax rate $(20 \%)$ to 
seek tax payable. This is confirmed by Mr. X as an employee of Malang City Revenue Service.

"If the implementation of the constraint system many tickets can be tricked. A bundle of tickets can be doubled, could be one of the ticket already porforated, and the other may not yet. Yesterday we found some issues like that, which reportedly limited perforated and reported that not in accordance with the turnover. It could be done by sometimes if the ticket didnot give to the customer, this matter is become a serious problem. Sometimes the customer received the ticket, but sometimes, they did not.." (July 6, 2017: 09:30 WIB).

\section{Unperforized Parking Lines}

The perforated ticket is a single form of supervision that already conducted by Dispenda Malang to verify the calculation of tax and reporting parking taxpayer turnover. The non-perforated parking lot led to a loss of parking tax potential because the parking manager has not been registered as a Taxpayer. It is known from Mr. $\mathrm{X}$ as an employee Dispenda Malang.

"Yes indeed if that has not been perforated yet, some of them are not yet recorded into the taxpayer, not become NPWPD." (July 6, 2017: 09:30 pm).

\section{Lack of Field Supervision}

The occurrence of irregularities found in the field is because of the opportunity. Field supervision is necessary to minimize the opportunity for the Taxpayer (in this case the Taxpayer of the Agency) to commit fraud by minimizing tax deposit or even not at all to give the tax to Dispenda. Parking manager of X Company admitted that the Dispenda Malang has never socialized it to the parking attendant.

"There is no socialization. Dispenda knew if the parking is not crowded like an always." (10 July 2017 : 13.00 WIB)

\section{Free Parking Policy}

From the observation to the field, there are several parking in Malang that apply the policy of free parking to the customer as a facility given to the customer. Some business locations that provide free parking as a facility to customers are not drawn by the business owner. Related to deposits and reporting, parking managers who apply free parking does not report and deposit Parking Tax to Dispenda Malang. This is known from the recognition of $\mathrm{Mr}$. $\mathrm{X}$ as an employee Dispenda Malang that the policy of free parking is not subject to parking tax.

"There are so many parking lot on the side road which managed by Dispenda, for example there are shop or caffee and there also the property owner that use that place, but the owner itself did not receive the charge because they already freed that parking lot. That is the facility of tax obligation and they are not taxed because its free." (6 Juli 2017: 09.30 WIB). 


\section{RESULT ANALYSIS \\ Lack of Parking Taxpayer Awareness}

Based on the findings from the field, taxpayers have the lack of awareness to give and report the parking tax to Dispenda Malang. The issue that encountered in the Malang City is a Taxpayer (in this case the Taxpayer Agency) does not deposit parking tax in accordance with the rules or even not at all to Dispenda Malang because they confess that they already deposited into the village treasury. This is from interview with Mr. X.

"The average of rented land is a Bangkok property so they thought that they already deposit to the village, they felt they already do his obligation to pay their taxes. ... he felt that he is just a villager, an indigenous person, so he thought there is an established tax object there. At the end, he paid the taxes not in accordance with the turnover. So he is just pay the taxes for just limited liability only. (July 6, 2017: 09:30 WIB)."

Furthermore, researchers found that parking revenues were shared their income between parking managers and the company. It is known that the distribution of parking revenue received by the parking manager gets $70 \%$ while the company gets $30 \%$.

"We share our income with the company, we do this because the company doing cooperation with the environment. So $30 \%$ for the company and $70 \%$ for the person who manage the field". (July 7 2017: 09.30 WIB).

Regarding the question of depositing and reporting the parking tax to Dispenda Malang, the parking manager seemed like to hide it. The parking manager admitted that Dispenda Malang had conducted socialization. However, the issue of parking taxes and reporting are done by the company.

"Dispenda already socialized abot parking tax and we are already asked that before because we really want to know about it, especially about the the regulation that is used and Dispenda already explained it. So we have a porporation from the local government and dispenda that already gave to us before, but for further explanation dispenda working together with the company." (7 Juli 2017:09.30 WIB)

To get information on parking tax deposit and reporting at CV X, the researcher tried to do inquiry to the management of CV X. Unfortunately, the management refused to conduct an interview with the researcher because of many emergency matters.

From the information above, the researcher concludes that the deposit and reporting of parking tax in $\mathrm{CV} X$ is not in accordance with the applicable regional tax regulation. This is related to the revenue sharing system between parking managers and the company. Other cases as mentioned above show that the awareness and level of knowledge about depositing and reporting the parking tax is still low because the taxes should be paid to the Dispenda not to the local village treasury. 
It is not just at the case above, the researcher found other deviation that happened in CV X parking. It is known from interview result with parking manager of CV X. The parking tax that already paid and reported only parking earnings obtained from $\mathrm{CV} X$ opening hours until 11.30. The rest of parking income is taken by the manager of the parking

"So, the parking income that already collected all which start from half past 12 that is when the company open and which is later need to deposit and report. Later at half past 12 the parking attendants will take it by theirself." (July 10 2017: 13.00WIB)

Based on the disclosure of the $\mathrm{CV} X$ parking manager, he found a fraud in depositing and reporting the parking tax payable. Parking managers only deposit and report parking revenue from $\mathrm{CVX}$ which is start open until 11.30, the rest is divided to the parking manager. Tax Evasion conducted by the parking manager by not depositing and reporting the taxed parking tax should clearly contradict the Mayor Regulation Number 15 of 2011 article 26 where the tax bases are the amount of payment or that should be paid to the parking lot organizer.

From the case above, it can be concluded that the potential income from the lost parking tax which directly impacts the local revenue (PAD). To overcome this leakage, Dispenda Malang should be more active in socializing tax regulations, especially tax regulations on parking tax. It is expected to increase taxpayers' awareness to comply with tax regulations. Firm sanction to taxpayers who do not apply taxation regulations, especially parking tax is considered to increase the parking lot manager awareness. For Dispenda party, supervision is very important to anticipate moral hazard which is conducted by Taxpayer. Supervision should be done randomly and routinely but the time is done randomly so Taxpayer is not orderly only at the time when the supervision.

\section{Self Assessment System Policy}

Based on the researchers' findings, the implementation of self assessment system is one of the obstacles in the parking tax collection practice in Malang City because this system gives the taxpayer the ability to calculate, calculate, pay and report his own taxes. Therefore, the implementation of this self assessment system can enable Taxpayers to commit fraud due to opportunities for the perpetrators.

Based on the findings, the parking manager of $X$ Company does not provide parking tickets if the parking lot users do not ask. Conversely, if the user requested a parking ticket, the parking manager gave it. This is acknowledged by the parking manager of $X$ Company

"Its just about the customer asks the ticket or not. If the customer asks for it, we will give it, otherwise it will not be given. "(10 July 2017: 13.00 WIB)

Based on the deposit and reporting of parking tax SOP, parking managers should be orderly in giving the tickets to the parking users, because the parking ticket is one of the surveillance media for Dispenda in verifying the calculations that have been done by the park manager in depositing and reporting the parking tax payable. The disorder 
of the parking manager of $X$ Company in giving the parking ticket to the user, causing the leakage of parking tax which affect the low PAD which obtained from parking tax.

Based on the parking deposit and parking reporting SOP, the manager should provide parking pass to the parking lot user, because the parking ticket is part of the Dispenda Malang supervision. This caused the loss of PAD from the parking tax which was deposited and reported to Dispenda Malang.

From the practice that occurred on the field, the implementation of self assessment system turned out to have an impact on revenue from the parking tax PAD. According to Albrecht et al. that one factor of people do cheating because of the opportunity. The implementation of the self assessment system and the ignorance of the parking tax subject regarding parking tickets that should be accepted gives the Taxpayer the right to commit fraud in depositing and reporting the tax payable.

To overcome this issue, Dispenda should monitor the field directly on a regular basis but the time is random to avoid the orderly taxpayer only at certain times. Supervision without official attributes is also one way to obtain evidence for improper taxpayer takings. In addition, socialization is considered necessary to Dispenda Malang and taxpayers, but also to the tax subject to cover the possibility of fraud opportunities that can be done by the taxpayer by not providing parking tickets to the tax subject.

\section{Unperforated Parking Ticket}

Based on the statement of Mr. X as an employee Dispenda Malang that if the manager of the parking lot has not applied the perforation ticket policy. Then the manager of that parking

lot has not been registered as a taxpayer and separated from the parking tax potential.

"Yes indeed if the ticket has not been perforated, it was not yet recorded into the taxpayer, not become NPWPD." (July 6, 2017: 09:30 pm).

In addition, it found parking managers who use parking charges retribution. This issue revealed by the parking manager of $X$ Company during this parking tax reporting by using the parking ticket retribution.

"Dispenda wants to ask for a ticket but there is only a ticket from dishub." (10 July 2017: 13.00 WIB)

Whereas parking tax and parking retribution is different. According to Mayor Regulation No. 15 of 2011, parking tax is defined as a tax on the off-street parking spaces provision, whether provided in connection with the principal business as well as provided as a business, including the provision of motorized daycare. Whereas according to the Regional Regulation of Malang City Number 3 Year 2015, parking fees are defined as payment for certain special licensing services (in this case is parking) provided and / or provided by the Regional Government for the benefit of individuals or company.

In the end both the parking tax and parking fees will going in to the local treasury of Malang City, but this thing will violates the existing regulations. Parking taxes are paid and reported to Dispenda Malang while parking fees are paid up and reported to Dishub Malang. It deals with the issue Administrative Compliance issue. The OECD 
(1999) in the Practice Note defines administrative compliance or formal compliance as compliance with administrative rules and correctness in paying the taxes, or it may be defined as compliance in reporting, procedural compliance and compliance with tax laws.

To overcome the existing problems, Dispenda at Malang City should impose the perforation ticket to all parking managers of in Malang City to anticipate taxpayers do Tax Evasion such as not deposit and report the taxes parking that should or even not to deposit and report the parking tax payable. Socialization is an important thing to overcome the taxpayers' ignorance problem about parking tax and parking fees. This thing is done in an effort to increase the level of tax compliance in terms of administrative compliance.

\section{Lack of Field Supervision}

Researchers found that the supervision in the field that conducted by Dispenda Malang is still less. This is known from the recognition of the $X$ Company parking manager who claimed that the Dispenda has never conducted socialization to the $X$ Company parking manager.

"There is no socialization. Dispenda knew if the parking is not crowded like an always." (10 July 2017 : 13.00 WIB)

The lack of field supervision impact causes leakage and loss of potential parking taxes due to fraud occasions by taxpayers who not deposit and report the taxable parking fees and as a result, PAD from the parking tax sector will decline.

To overcome the leakage and parking tax lost potential due to lack of field supervision, Dispenda must conduct a more rigorous and routine supervision also should to it at the random time so that taxpayers are expected not only at the time of supervision only. The existence of severe sanctions and penalties to the parking lot managers that are not in accordance with the tax regulations, especially parking taxes can reduce the fraud that occurs in practice.

\section{Free Parking Policy}

Based on the findings that related to the free parking policy, it was found that parking lots that impose a free parking policy are not subject to parking tax. This is due to the assumption that free parking is a form of facilities from the owner of a business given to its customers for free, free of charge so as not to be subject to parking tax. It is known from Mr. $X$ as an employee Dispenda Malang.

"A tax means that if there is a land and there it becomes a place of business that becomes a business place and they attract a fare to the citizens (the public) it can become the subject to parking tax. However, there is land from the businessman but does not attract a fare for parking problems, of course it can not be subject to parking tax." (July 6, 2017: 09:30 pm)

The existence of field practice differences with written regulations in the Malang city causes a problem which is the parking tax that should be levied by taxpayers become a thing that should not be levied. In Regional Regulation No. 16 of 2010 Article 49 states that Parking Tax Objects are the off-street parking spaces provision, whether 
provided in connection with the principal business as well as provided as a business, including motor vehicle and free parking provider as a form of service to its customers. Things that are not include to Parking Tax Objects are (a) Provision of parking spaces by the Government, Provincial Government and Local Government; (b) the provision of parking space by a company that is only used by its own employees. Regarding the procedure of calculation is by multiplying the tax base (DPP) with a rate of $20 \%$. The free parking space as a form of service to its customers is the object of the parking tax so that the collection of fixed parking tax must be made to the user, unless used by the employee themselves. The inconsistency between field practice and Local Regulation No. 16 of 2010 caused a potential loss of parking tax and the impact would have an impact on the decline in PAD. This is because there are quite a lot of parking spots that implement free parking policies.

To solve this problems, Dispenda Malang must determine the clarity regarding the parking tax imposition on parking lot that apply free parking policy. This uncertainty will affect the Dispenda Malang performance in managing the parking tax potential in Malang. If it is based on tax regulations, especially the parking tax, then the action that must be done is by conducting field supervision on parking management locations that implement the free parking policy. Socialization is also needed to improve the understanding of taxpayers on tax regulations, especially parking tax.

\section{SOP IMPROVEMENT OF REGIONAL TAXPAYER FINANCIAL SYSTEM AND FISCAL PROPOSAL \\ SOP Improvement of Taxpayer Registration}

\section{Required documents}

The first step to get the NPWPD is parking manager need to prepare and fill the files, including: (1) Taxpayer Registration Form; (2) Photocopy of Identity Card $(K T P)$;

(3) Photocopy of Family Card (KK); (4) Photocopy of Trading Business License (SIUP); (5) Domicile Letter of Business Place (if business address is different from $K T P)$.

\section{Party Involved}

(1) Parking Manager; (2) Data collection and registration Section(BP2D); (3) Data processing and information Section (BP2D).

\section{Procedure}

1) The files are submitted to the Malang Regional Revenue Office at Data Collection and Registration Section during work.

2) After being received by Data Collection and Registration Section, verification of the files covering the tax subject verification and tax object (field verification). If the files are complete and suitable, Data Collection and Registration Section forward the file to the Data and Information Processing Section.

3) Data and Information Processing Section is assigned to record the data of Taxpayer and Taxpayer Identification Number (NPWPD). The process of making NPWPD cards is 3 days after the files are received by Data and Information Processing Section. 
4) Upon received of the NPWPD card, the parking manager has legitimately become a Parking Taxpayer and is obliged to report and deposit 20\% of Parking Tax from the parking income for the following month and so on.

5) Once registered into a Mandatory Parking Tax, parking managers are obliged to collect parking tax from the Parking Tax subject or parking users. Because the Regional Revenue Service does not have a SOP for the Parking Tax collection from the tax subject to the taxpayer, the researcher makes Parking Tax Collection SOP.

6) BP2D Malang City must monitor the taxpayer agency of parking every three months. Monitoring is done either checking the existing database or plunge directly into the field. It aims to reduce the existence of tax evasion in Malang City conducted by corporate taxpayers.

\section{SOP Improvement Tax Parking Taxation by Taxpayer Agency}

\section{Required Documents}

(1) Vehicle License (STNK); (2) Ticket; (3) Notes; (4) Daily cash receipt book; (5) Daily cash receipt report; (6) Proof of deposit to the bank; (7) Daily cash receipts.

\section{Party Involved}

(1) Parking users; (2) Taxpayer Agency; (3) Treasurer of Taxpayer Entity; (4) Bank; (5) Accounting and Finance Section

\section{Procedure}

1) The parking user asks for a ticket by showing the vehicle License to the Taxpayer Agency.

2) Taxpayer Agency checks vehicle license with vehicle parking number plate. If it does not match, then the parking user can not sign in. If suitable, then the Taxpayer Agency give the ticket and return the vehicle registration to the parking user.

3) Parking users will park their vehicle.When the user is parked back, then he / she must show the vehicle license and the ticket.

4) Taxpayer Agency checks for vehicle registration and parking fee. If it is suitable, then the parking user pays the parking amount. Then Taxpayer Agency will return the vehicle license and provide printed parking notes. If it does not match, then parking users have to pay a fine. If you already pay a fine, then the WP Agency will return the vehicle license and provide printed parking notes.

5) Based on the parking note, Taxpayer Parking Division Manager Agency make daily cash book in 2 copies, $1^{\text {st }}$ duplicate submitted to the Treasurer Reception of Taxpayer Agency, $2^{\text {nd }}$ duplicate for archive. Subsequently the Manager Department creates a Daily Cash Receipt Report of 2 copies, 1st duplicate is given to the Accounting and Finance Section, $2^{\text {nd }}$ duplicate for archive.

6) After the Reception Treasurer receives a daily cash register, he goes to the Bank to deposit parking user parking fees into the taxpayer agency's account. The Bank receives the money and prints the deposit proof as much as 2 copies, 2 copies are given to the Receiving Treasurer, $1^{\text {st }}$ duplicate for archive. 
7) The treasurer replicates 1 copy of deposit proof to the Bank, original proof of payment is given to the Accounting and Finance and the prints are archived.

8) Based on the Daily Cash Receipt Report from the Taxpayer's Parking Management Agency and bank deposit evidence from the Reception Treasurer, Accounting and Finance Section shall journalize, then make a ledger. Then the next process is to make a Financial Statement of Cash Receipts.

\section{Sop Improvement of Parking Tax Report and Deposit}

\section{Document Required}

(1) SPTPD; (2) parking ticket / turnover report; (3) Parking payment recap; (4) BKU (General Cash Book); (5) SSPD; (6) STS.

\section{Party Involved}

(1) Taxpayer; (2) Services and extension section; (3) application section; (4) Treasurer

(5) Bookkeeping section

\section{Procedure}

1) Taxpayer agency calculates the profit total of parking income for 1 month.

2) Parking taxpayers are required to report the profit and calculate Parking Tax on profit by $20 \%$ using SPTPD to Regional Revenue Office of Malang City. The limit of SPTPD submission and tax refund is 10 days after the expiration of the tax period.

3) The files are submitted to the Regional Revenue Office of Malang City Service and Extension Services section for verification of the completeness of the file.

4) If the files are complete and suitable, then the files are forwarded to the Determination Section to do the recalculation of the taxpayer calculation by checking the files that exist.

5) If the tax calculation result according to the Parking Taxpayer is in accordance with the calculation of the Stipulation Section, the taxpayer may pay the tax of the tax payable to the Treasurer Reception.

6) From the tax payment, the Reception Treasurer prints SSPD based on the SPTPD which has been recalculated by the Stipulation Section as a proof that the Parking Taxpayer has paid the Parking Tax.

7) After printed, SSPD is given to the Mandatory Parking Tax as payment proof of Parking Tax. After receive the Parking Tax invoice from the parking taxpayer, the Treasurer Reception makes the BKU receipts and deposit report to make STS.

8) STS as the basis for making the Local Tax Realization Report by the Bookkeeping Section and as a tool to deposit all tax revenue.

9) $B P 2 D$ Malang must monitor the taxpayer of the parking agency every three months. Monitoring is done either checking the existing database or plunge directly into the field. It aims to reduce the existence of tax evasion in Malang that conducted by corporate taxpayers. 


\section{Conclusion And Limitation}

Conclusion from this research are (1) SOP that are ran in the parking tax collection practice are considered have a gap of tax evasion, so it is necessary to improve SOP to reduce the Tax Evasion that may be done by Taxpayer. Local Regulation No. 16 of 2010 on Local Taxes and Regulations of the Mayor Number 15 Year 2011 on Payment Procedures, Deposits, Payment Places, Installment and Delay of Regional Tax Payments is also considered not running well because there are Taxpayers who do not deposit payable parking taxes and report also they don't provide parking tickets to tax subjects. To minimize leakage and loss of parking tax potency, Dispenda Malang City should do more strict supervision, including with supervision without official attribute also need to be done to facilitate Dispenda to find disorder parking management evidence. (2) Parking tax collection in Malang has several problems, because (a) Lack of Parking Taxpayer awareness;

(b) Implementation of Self Assessment System; (c) Unperforation ticket; (d) Lack of field supervision; (e) Free Parking Policy.

As a result of these problems, it cause leakage and potential loss of parking taxes that resulted declining of PAD from the parking tax sector. To overcome these issue, then Dispenda Malang socialize thoroughly both to the parking manager and to the parking user so that parking managers will understand with the obligations and parking users can participate oversee the activities of parking tax collection. The existence of sanctions for the disorder of parking lot and strict supervision can also be done to minimize the opportunity of parking managers to do cheating.

This research has limitations, they are (1) The researcher is not directly involved in parking tax collection. Researchers only investigate the results of interviews with informants and observations by being a parking user, then checking applicable tax regulations and SOP of parking tax that already applied in Malang City. The absence of researchers in the parking tax collection practice allows the existence of confidential information that is not yet known by researchers. (2) Researchers can not dig further information in some parties such as the management of $\mathrm{CV} X$ and some parking managers in the Malang city who seemed to cover some information related to the collecting parking tax practice in Malang. (3) This study only digs related to the practice of parking collection in Malang. In this study did not discuss related to parking taxes that are less or more paid as well as objections to parking tax payable. 


\section{References}

Albrecht, Steve W, Chad O. Albrecht, Conan C. Albrecht \& Mark F. Zimbelman. 2012. Fraud Examination. South-Western CENGAGE Learning. Page. 34.

Camerer, Colin, et al. 2005. "Neuroeconomics: How Neuroscience can Inform Economics". Journal of Economic Literature. Vol. XLIII. hlm 9-64.

Camerer, F.C. 2006. "Neuroeconomics: Using Neuroscience to Make Economic Predictions". This Paper was Prepared for The Hahn Lecture. Nottingham UK: Royal Economic Society.

COSO. 2013. Internal Control-Integrated Framework : Executive Summary. Durham, North Carolina, May 2013.

Daniri, Mas Achmad. 2005. Good Corporate Governance: Konsep dan Penerapannya Dalam Konteks Indonesia. PT Ray Indonesia. Jakarta

Fajriana, Nadia. 2017. Analisis Praktik Pemungutan Pajak Parkir Di Kota Batu.Jurnal IImiah Mahasiswa Feb Ub.

Hartatik, Indah Puji. 2014. Smart Books Make SOP (Standard Operating Procedure). Yogyakarta: Flashbooks.

Hartono, Jogiyanto. 2005. Information System Analysis and Design. Yogyakarta: Andi.

Kendall, K.E \& Kendall, J.E. 2003. System Analysis and Design. Jakarta: Prehallindo.

Mardiasmo. 2009. Taxation. Yogyakarta: Andi.

McCabe, K. A. 2003. "Neuroeconomics". Encyclopedia of Cognitive Science, Vol. 2, No. 3, pages 294-298.

Moekijat. 2008. Personnel Management and Human Resources. Yogyakarta: BFFE.

Nugroho, Riant. 2004. Public Policy, Implementation and Evaluation Formulations. Jakarta: Gramedia.

OECD. 1999. Compliance Measurement-Practice Note. Centre for Tax Policy and Administration (CTPA). General Administrative Principle (GPA)-GPA004

O'Brien, James A. (2005). Introduction to Information System, 12th Edition. McGraw Hill Companies Inc., New York

Peraturan Daerah Nomor 16 Tahun 2010 Tentang Pajak Daerah

Peraturan Wali Kota Nomor 15 Tahun 2011 Tentang Tata Cara Pembayaran, Penyetoran, Tempat Pembayaran, Angsuran Dan Penundaan Pembayaran Pajak Daerah.

Ratsminassiwi, Chandry Dyah \& Hendi Subandi. 2017. The Effect of Fraud, Personal Trends, and Technology of the Taxation System on Tax Revocation (Case Study on Hotel Taxpayers Registered in Malang City Tax Offices). Scientific Journal of FEB UB Students, Vol. 5, No. 2, 2017.

Resmi, Siti. 2013. Taxation Theory and Cases. Jakarta: Salemba Empat.

Romney, Marshall B. \& Paul John Steinbart. 2015. Accounting Information Systems. Jakarta: Salemba Empat.

Sailendra, Annie. 2015. Practical Steps to Make SOP. Yogyakarta: Trans Idea Publishing. Siahaan, M. P. 2010. Regional Taxes and Regional Levies. Jakarta: Grafindo.

Stair, M. Ralph, George W. Reynolds. (2010). Principles of Information Systems: A Managerial Approach. (9th edition). Australia : Thomson Course Technology. 
Sudarma, Made \& Ayu Fury Puspita. 2017. Neuroeconomics: An Introduction as a Perspective in Tax-Planning. Presented at: SIBR-RDINRRU 2017 (Sydney) Conference on Interdisciplinary Business and Economics Research, 15th - 16th April 2017, Sydney, Australia.

Turban, E. 2005. Decision Support Systems and Intelligent Systems Edisi Bahasa Indonesia Jilid 1. Yogyakarta: Andi.

Undang-Undang Nomor 16 tahun 2009 Tentang Ketentuan Umum Perpajakan.

Zain. 2007. Tax Management. Edisi 3 2007. Jakarta: Salemba Empat

Zain, Muhammad, Suryo Hermana. 2010. Taxation Law Association 2010. Jakarta: PT Indeks. 
